3 Colwell JA, Winocour PD, Lopes-Virella M, Halushka PV. New concepts about the pathogenesis of atherosclerosis in diabetes mellitus. Am $\mathcal{F}$ Med 1983;75:67-80.

4 Jones RL, Peterson CM. Hematologic alterations in diabetes mellitus. Am $\mathcal{F}$ Med 1981;70:339-52.

5 Laakso M, Rönnemaa T, Pyörälä K, Kallio V, Puukka P, Penttilä I. Atherosclerotic vascula disease and its risk factors in non-insulin-dependent diabetic and nondiabetic subjects in Finland. Diabetes Care 1988;11:449-63.

6 Wingard DL, Barrett-Connor E, Criqui MH, Suarez $\mathrm{L}$. Clustering of heart disease risk factors in diabetic compared to nondiabetic adults. Am $\mathcal{F}$ Epidemiol 1983;117:19-26.

Stout RW, Bierman EL, Ross R. Effect of insulin on the proliferation of cultured primate arterial smooth muscle cells. Circulation Res 1987;36:319-27.

8 Nakao J, Ito H, Kanayasu T, Murota S-I. Stimulatory effect of insulin on aortic smooth muscle cell migration induced by $12-\mathrm{L}$-hydroxy-5, $8,10,14$-eicosatetraenoic acid and its modulation by

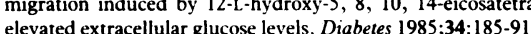

$9 \mathrm{Kaji} \mathrm{H}$, Kurasaki $M$, Ito $\mathrm{K}$, et al. Increased lipoperoxide value and glutathione peroxidase activity in blood plasma of type 2 (non-insulin-dependent) diabetic women. Klin Wochenschr 1985;63: $765-8$.

10 Bodnar PN, Donish RM, Pristupiuk AM. Interrelation of diabetes mellitus, atherosclerosis and ischemic heart disease. Ter Arkh 1984;56:88-92.

11 Hessler JR, Morel DW, Lewis J, Chisolm GM. Lipoprotein oxidation and lipoprotein-induced cytotoxicity. Arteriosclerosis 1983;3:215-72.

12 Quinn MT, Parthasarathy S, Fong LG, Steinberg D. Oxidatively modified low density lipoproteins: a potential role in recruitments and retention of monocyte/macrophages during atherogenesis. Proc Natl Acad Sci USA 1987;84:2995-8.

13 Jarrett RJ. Type 2 (non-insulin-dependent) diabetes mellitus and coronary heart disease-chicken, egg or neither. Diabetologia 1984;26:99-102.

14 Jarrett RJ, Shipley MJ. Type 2 (non-insulin-dependent) diabetes mellitus and cardiovascular disease-putative association via common antecedents; further evidence from the Whitehall study. Diabetologia 1988;31:737-40.

\title{
A core medical curriculum
}

\section{Two recent reports presage changes in medical education}

The education committee of the General Medical Council (GMC) has recently quietly reviewed the teaching of the clinical and diagnostic disciplines in British medical schools.' Some of the details of the council's report are curiously consonant with the "Edinburgh declaration" from the world conference on medical education despite the Edinburgh report reading somewhat like an educational revelation from St John the Divine (Report of the world conference on medical education, Edinburgh, 1988). Yet the Edinburgh conference was in little doubt that medical education is up a gum tree whereas the GMC report concludes that "there is a vigour in the pursuit of the delivery of medical education, and a diversity of opportunity that is impressive" and that "the council's recommendations on basic medical education are everywhere being followed." Reading between the lines we detect concerns at the GMC about the state of British medical education.

Surprisingly, the council's report shows considerable differences among schools in the form of their clinical courses. The length of surgical clerkships (and its specialties) ranges from 13 to 36 weeks; the size of teaching groups in psychiatry ward rounds varies from one to 14 studentş; students may spend from six to 50 weeks doing clinical work away from the main teaching centres; and in two schools about 90 necropsies are seen by students whereas in another they are "probably" not attended at all by many students. Eight schools provide no patient contact in the preclinical period, and three schools have no curriculum committee. Student research is little encouraged; the taking of intercalated degrees is often dependent on personal finance, and the degrees are rarely taken in clinical departments. The separation of pathology from clinical teaching is seen as possibly impairing an understanding of their interrelations. The "second $\mathrm{MB}$ barrier" still exists in most schools, and with the exception of those from departments of psychology and sociology few preclinical teachers contribute to the clinical teaching. Finally, although schools accept the importance of teaching communication skills, many provide no formal teaching and have not identified ways of doing so or assessing communication skills. Overall the curriculum is seen as "already overcrowded," with exposure to some subjects being so brief as perhaps to be without benefit. The possibility thus arises of the education committee stipulating a "core course with options."

The Edinburgh declaration specifies 24 steps for an "international collaborative programme for re-orientation of medical education." Despite-or perhaps because of - the revolutionary and idealistic sentiments of the Edinburgh report the likelihood of a radical change in undergraduate medical education in Britain seems remote in the short term. Resources are too restricted, and the apparatus of medical education contains too much friction and inertia. But if such a revolution is to occur then it may well come from the GMC's own education committee, which has for many years succoured and supported the institutionally unfashionable and underresourced subjects of behavioural sciences, community medicine, and general practice. ${ }^{2}$ The education committee may well find many of its sentiments set out within the Edinburgh declaration. Thus under "competence in individual diagnosis and management" the report states:

"Students have to learn to listen to patients attentively, to look at them with the intensity of the trained observer, and to communicate well with patients, relatives, and other health professionals. They must also learn to prevent and treat common disorders, to keep clear the accurate records, to handle common emergencies and also about rehabilitation. They must learn to recognise when they must seek help from others."

The action needed to achieve such a goal is to "define the essential core of knowledge and professional competence which is required ..." (our emphasis). The definition of a core curriculum, previously advocated by students themselves, ${ }^{3}$ is now technically feasible with methods such as the critical incident technique in which thousands of real medical events are analysed to determine the skills needed to do the job. ${ }^{4}$ Core syllabuses in each subject - perhaps determined by consensus conferences organised by the GMC - would not only reduce curriculum overloading but also might help to shift the educational emphasis away from being taught towards actively learning.

Senior Lecturer in Psychology Applied to Medicine,

I C MCMANUS

St Mary's Hospital Medical School,

London W2 $1 \mathrm{NY}$

Senior Research Associate,

R E WAKEFORD

Office of the Regius Professor of Physic,

Cambridge University School of Clinical Medicine,

Cambridge CB2 2QQ

1 General Medical Council Education Committee. Report of a survey of medical education practices in United Kingdom medical schools. London: General Medical Council, 1988.

2 General Medical Council Education Committee. Report of a working party on the teaching of behavioural science, community medicine and general practice in basic medical education. London: General Medical Council, 1987.

3 Cruickshank JK, Barritt PW, Besag FMC, Waterhouse N, Goldman LH. Student views on continuous assessment at Birmingham University. Br Med f 1975;iv:265-7.

4 Anonymous. Critical questions, critical incidents, critical answers [Editorial]. Lancet 1988;i:1373-4. 